\title{
頸部内頸動脈の特発性解離性動脈瘤
}

\author{
CT scan 所見と治療を中心に
}

伊藤 義廣·伊東山洋一・福村 昭信·松角 康彦* . 児玉 万典*

\section{Dissecting Aneurysm of the Cervical Internal Carotid Artery}

Cervical CT Scan Findings and Treatment - Case Report-

\author{
Yoshihiro ITOH, Youichi ItOYama, Akinobu Fukumura, Yasuhiko Matsukado* \\ and Takafumi KODAMA* \\ Department of Neurosurgery, Shimonoseki Kosei Hospital, Shimonoseki, Yamaguchi; ${ }^{*}$ Department of \\ Neurosurgery, Kumamoto University, Kumamoto
}

\begin{abstract}
On lifting a heavy case, a 51-year-old male experienced a sudden onset of headache with giddiness and clouded vision. A week later, vertigo and right hand numbness were added to his symptoms. The next day anisocoria (right $>$ left) and dilation of the left retinal veins were noted. Cranial computed tomography (CT) scan appeared normal and there were no other remarkable neurological findings. The patient was treated conservatively for cerebral infarction, however, the headache worsened and diplopia occurred. Neurological examination on admission revealed nothing unusual except for left Horner's syndrome. Physical examination showed a palpable sausage-like painless tumor on the left side of the neck. Angiography showed a narrowing of the internal carotid artery in the cervical region with a small dissecting aneurysm at the C3 level. Cervical CT scan at the upper C3 level showed a low density lunar defect in the high density section of the enlarged left internal carotid artery. The patient was operated on by superficial temporal artery-middle cerebral artery anastomosis to increase the intracranial blood flow. Postoperatively the symptoms were quickly relieved. Angiography 1 month later showed less narrowing of the carotid artery, though the dissecting aneurysm still remained. Postoperative cervical CT scan showed the left internal carotid artery to be of normal size. The patient returned to his work in normal condition 2 months later. It is emphasized that cervical CT scan may be useful in the diagnosis of this unusual type of cervical dissecting aneurysm.
\end{abstract}

Key words: dissecting aneurysm, internal carotid artery, computed tomography

\section{I はじめに}

頸部内頸動脈の狭窄性病変の多〈は動脈掩化性ひものて あるが，まれに解離性動脈瘤に上るもの力゙ある。以前は剖 㭥にて初めて明らかにされた拝例が多かったが，近年，臨
休所見，血管写所見より診断され，良好な経過をとる症例 が多数報告さ机ている。我々女特異店 CT scan 所見を示 し，良好な経過を辿った拝例を経験した。CT scanは，本 疾患の骖断にも有用であると思われた。さらに，治療法と 予後炕ついて文献的考察を加えて報告した。 


\section{II 症例}

〈患者〉51才，男性

家族歴：特記一ざさこ上なし

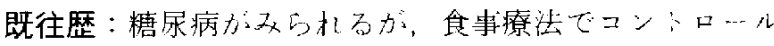
されていた，梅毒の既往もない，

現病歴：1984年 8 月 12 日，博先のホテルのロビーート ランクを持り上げた僢閒，急にふらつを感し，车眼の暗 黑感を伴一心，左眼窝深部痛もるったダ，什事を続けてい た。8月19日朝，数分間で改善する回転性Hまいを感じ， 台手しびれ感加加ったため，8月20日，当科高受診し た。

初診時，頭痛，瞳孔不同(在>左)，左腿底網膜細静脈 $\sigma$ 万つ血，右手しび扎感以外以は明与かな神释学的異常はな 加大，頭部単純 CT scan は正常所見で，脳波以左半球 優位の slow wave り混入辛涩めた。脳梗塞上診断し，薬物

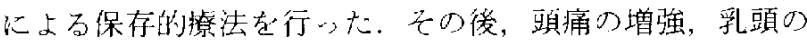
発亦，上方法視時の diplopia 加出現し，8月29日，入院し た。

入院時所見：身体所罗上して，庄頸部にン一セージ状の

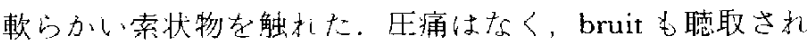

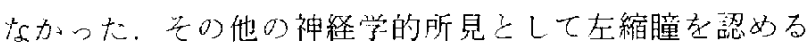
が，问側の発汁異常占なか心な。他覚的には感筧・運動麻

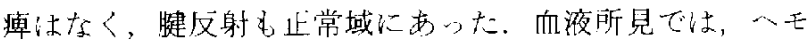
グラム，出血時間，膠質反応，口ッェルアン反応など正常 であり，血沈も1時間值 $7 \mathrm{~mm} ， 2$ 時間值 $14 \mathrm{~mm}$ と正常で あったが，向糖值は食的 $86 \mathrm{mg} / \mathrm{d} l, 1$ 時間後 $180 \mathrm{mg} / \mathrm{d} l, 2$ 時間後 $162 \mathrm{mg} / \mathrm{d} l$ と軽度の異常を認めた。脑部単純写真, 心電图我正常ですかた。

神経放射線学的所見:9月5口，血管撮影を施行した。 左内頸動脈俚分岐部上り称 $5 \mathrm{~mm}$ 米梢で急に狭小化し，頭

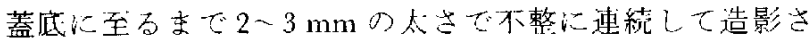
炕 (string sign)，㹨窄起始部後力に $8 \times 3 \mathrm{~mm}$ の解離性動脈 瘤が存在した。さシに，頭蓋底部での最强狭窄部の後で止 常の太さに戻り，頙蓋们内頸動脈上は簧常はなか一た

(Fig. 1)，在 CAG，雨側VAGでも起始部を初め異常はみ ら扎なかった。A1を分しての左半球への cross circulation が認めら水た。9月10日，频部 C T scanを施行したとこ

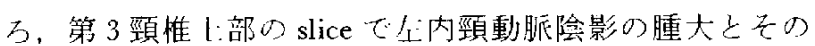
内部に半月型の low density areaがタらら扎た (Fig. 2A)。

入院後経過：9月10H頃沁は縮瞳は消失したか，他の证 状は変化なかった。血沈は 1 時間値 $70 \mathrm{~mm}, 2$ 時間值 110

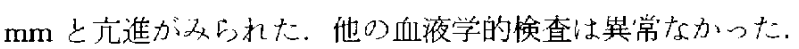
9 月13日, 左 STA-MCA anastomosis 施行, 術後速や力 に頙痛，右手しびれ感は消失した。しかし，左眼の網膜細
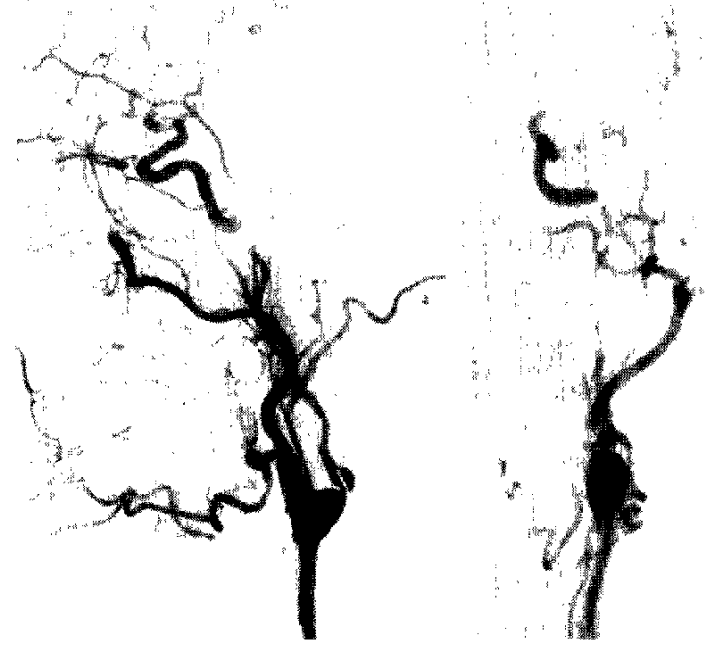

Fig. 1 Left carotid arteriograms showing a dissecting aneurysm and narrowing of the cervical intcrnal carotid artery. left: Lateral view, right: Antero-posterior view
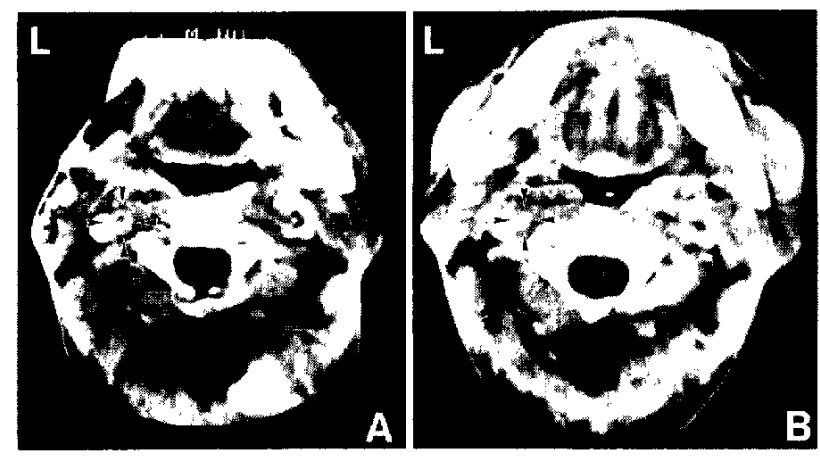

Fig. 2 A: Cervical computed tomography (C'l) scan showing a lunar-shaped low density defect in the enlarged left internal carotid artery at upper C3 level (arrowheads). B: Postoperative cervical GT scan showing a section of the left internal carotid artery, normal size, at lower C2 level (arrowheads)

静脈らっ血は続いた。10月3日の術後孟管撮影ては, 狭窄 部は・部を残し改善していたが，解離性動脈瘤法同様に認

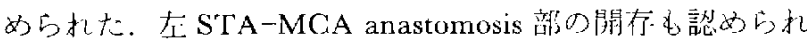

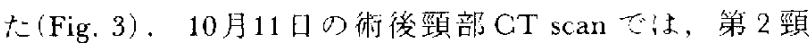
椎下縁で左内頸動脈は在側上汪洼同大で円形に造影さ扎て いた(Fig. 2B)。项部妳状物は触知さ礼なくなり，10月13 日，退院した，同年11月，前職に復し，現在，身体的にb 臨床的に異常を認めていない。 

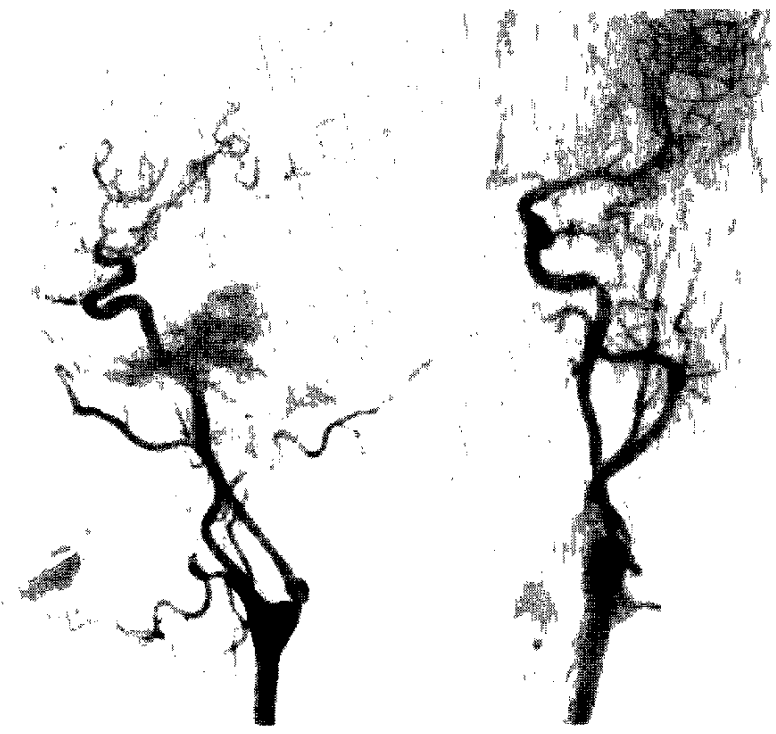

Fig. 3 Postoperative left carotid arteriograms showing improvement of the stenosis of the left internal caratid artery. The dissecting aneurysm is still visible. left: Lateral view, right: Antero-posterior view.

\section{III 考 察}

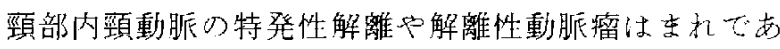
り，従来をの診断む容易ではなからた。これまで文献的報

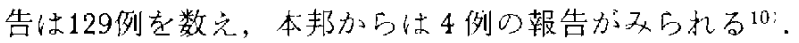

·般に，急激な腷梗塞で発症，短時間で死亡し，剖険で明 らかにされる症例が多かったが，近华，血管写での特有た 所見より診断され，予後良好例毛多い。

これらの病変は，血管写所見を基に二つの typeに分计 ることが可能である。一一は狭窄性変化を六すもので，そ の血管写上の所見上しては string sign (long irregular filling defect), post sinus tapering occlusion などと呼称されるもの があり，他力は異常血管陰影を有する例で, dissecting aneurysm, intimal flap と呼称さ扎る那見を呈する。これら の本態は同一のむのであり, 解離部位上断裂部上の関保, 血液流入の有無，血栓の部位などでそれぞれの差違がある

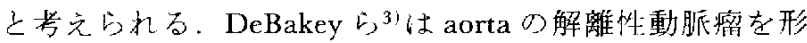
態的に 3 型に分頑し，その治療について論じているがこ こで述べる狭窄性変化を示す type はそのI型に相当し， 異常血管陰影を手す type はII ・ III型に相当すると考完る (Fig. 4)。李た，顡部内領動脈の解離性動脈瘤の形態につ いて，Friedman $5^{51}$ は自験例13例より 4 型に分類し，図 示して招り，狭窄性変化を示寸 type 蛙の A, B に当り， 巽常陰影を示与 type は C, D に“る之考兄る(Fig，5)。さ らに, Friedman ら $5^{51}$ 注自験例を同様に分類すると，9例が
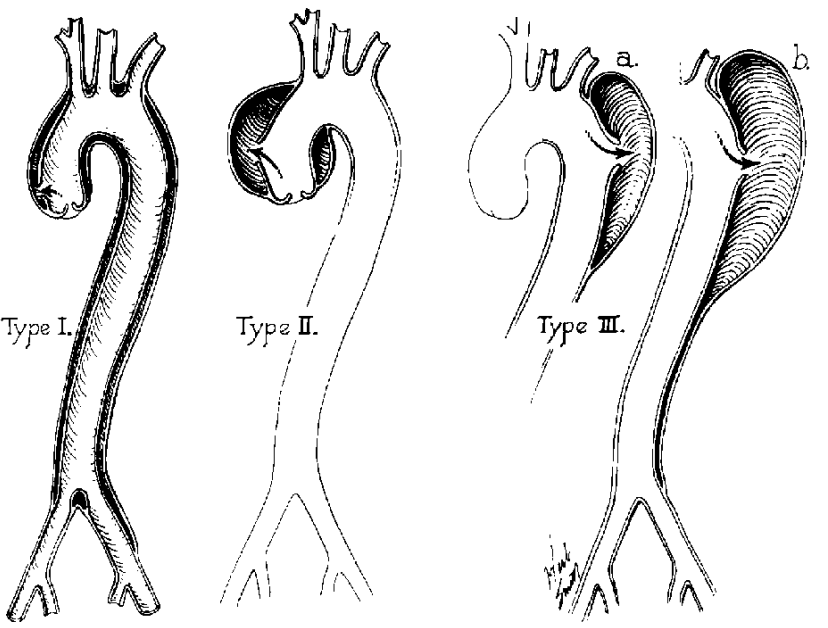

Fig. 4 DeBakey's classification ${ }^{31}$ of dissecting aneurysms of the aorta. Reproduced with permission from DeBakey et al.: Surgical management of dissecting aneurysms of the aorta. J Thorac Cardiovase Surg 49: 130-149, 1965.
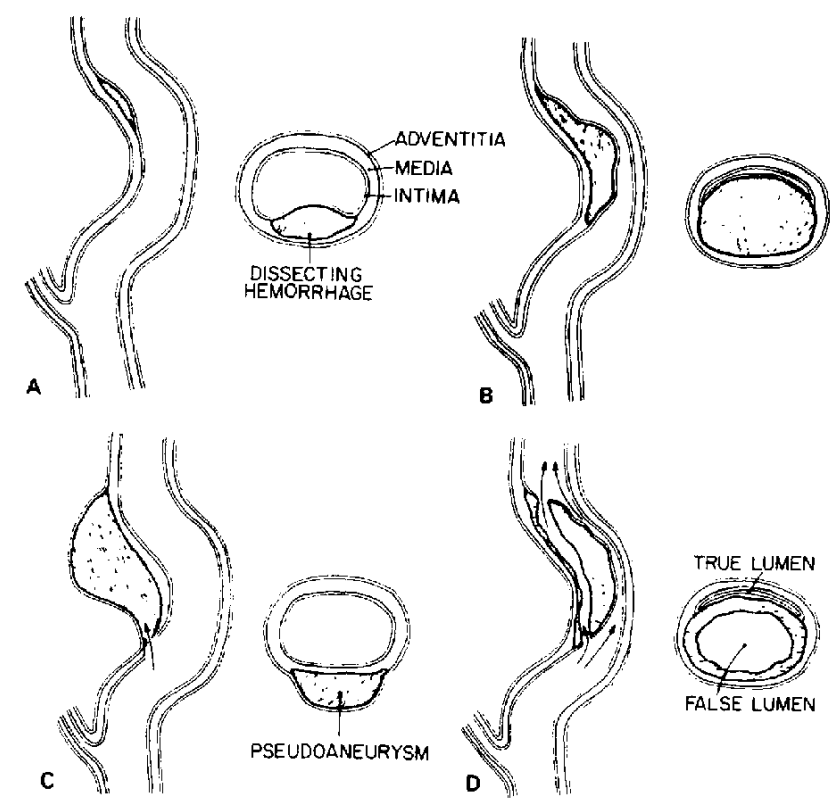

Fig. 5 Friedman's schema ${ }^{5}$ of dissecting aneurysms of the internal carotid artery. Reproduced with permission from Friedman et al: Cervical carotid dissecting aneurysms. Neurosurgery 7: 207-214, 1980.

狭窄吽炃化を呈し，4 例が巽常血管陰影を有して招り，狭 窄性変化を呈した患者の恅往歴には異常かなかったか，異 常血管陰影有した患者のすべてに trauma, fibromuscular dysplasia 在どの既往歴の異常がタられたといら．発生部 位については，aortaから連続して存在する拝例孝除き， 
末梢性以発牛する例は䫓蓋外内頸動脈のいずれの部位にも 欢られる。しかし，内頸動脈の分岐部上り2 - $3 \mathrm{~cm}$ 以内 长発生が多く，頭蓋底に達す名 $2 \sim 3 \mathrm{~cm}$ 末梢部付近には

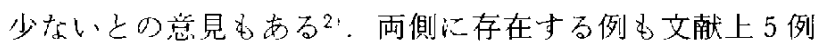
ある1,5! しかし，狭窄性変化を早与を例，異常陰影を呈 寸る例について性発生部位における差はないと思初れた。

特癹性動脈解離の病態は，血管队膜の断裂部力。解離 $\mathrm{L}$ た中膜腔に血液が流入し，false lumen 老形成，元の以腔 な狭窄したものであるが，正常の状態にある中膜で起こ り完ず，中膜解離の状態が先に存在していだはずである。 中膜解離の原因は，主にcystic medial necrosisであると言 われる。さらに，ての原因として vasa vasorumの動脈便 化次上る閉塞や congenital 质因子, toxic 変化, trauma などが挙げられているが，明らかてはない、8,14．先に存在 与る中膜解離の㳎がりや程度，内膜断裂の部位や大きさて 形態の差があると思执扎る。次汇，内膜断裂の原因として 潜在的動脈硬化汇よる intimal erosion, minor trauma, hyper-extensionなどが挙げられている101. また，中膜変性 の進行の結果，病栄部でvasa vasorum の破裂が起こり， これが引金となる上も言われる14．発症について，本例で は重い荷物を持ち上げた橓間，症状を自覚して坔り，血厈 上䒜，頸部筋肉の緊張などによる血管への内外からの力が 加わのて破裂が起こったと考光られたが，特発例の報告电 あり，定かではない。

臨米症状に扣ける顔面痛，片側頭痛，笑発吽に起こる眼 や脳の虚血性变化は脳動脈硬化性病变でも起こり，必ずし も特有ではない、しかし，内頸動脈周目の解離により交感 神経が障忠されて起こるホルネル症候群は特徴的であり, 外頸動脈の交感神経は障噩されないため，発汗障壱を伴わ ない. Mokri ら (2)は13例中5例 (38\%)に認められたと述 ベ,この所見と片側頭痛，顔面痛を伴う場合，臨床症状で 診断叮能であるという。本症例でも同様症状が認めら机 た。ささらに，本症例では上䫓部にンーセージ状の腫瘤を触 れた，病変部が高位置のもの，小腫瘤である場合，あるい， は頸部の肥满などて触れ之ない場合もあるが，大きな拍動 性腫瘤として発見される症例るあり，触診所昌は重要であ 万.

CT scan 上，胸腹部大血管の解離性動脈熘では管腔の抬 張 - 不整, 異常突蛙膨隆, 壁肥㫗の所見に加党, enhancement studyでは三口月型などの解離腔が描出されるとい $5^{13,15)}$. 特にbolus injection によって, 最初に真血管挖が 造影され，ついて均心造影，遅れて解離腔が增强され (delayed filling)，さらに造影䨩の排出生延(delayed washout)がみられると言われる411.これらの所見は先述 のDeBakey 豆の分類の type II ・ IIIにみられるもので,

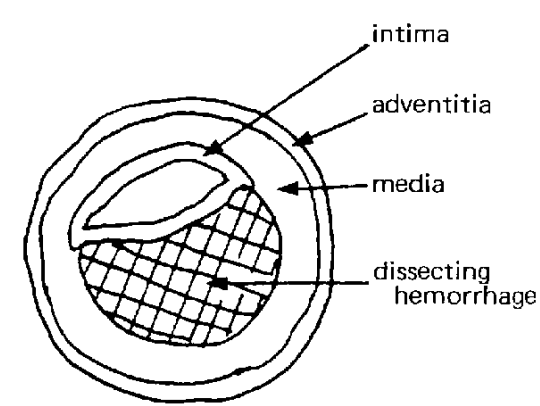

Fig. 6 Cross-sectional schematic view of the left internal carotid artery at upper cervical G3 level in our case.

type Iでは血管内に造影欠損として描出される血栓の存 在, 膜状に enhanceされない部として現れる intimal flap, 血管陰影内に残る外壁の石灰化所見 (calcified intimal displacement)がみられることがある7). 頸部血管は本来佳 が小さく，CT scan 画像で明瞭に捉えがたい。 また，症例 もまれなためこれまでその所見の報告を㴗かにみない が，本症例は発症後 1 力月目に通常の造影法で特有な所見 が得られた点，注月心值する．血管写所見とも合せ考学る

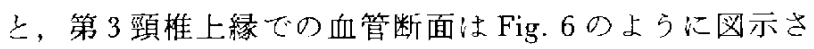
れる。CT scan 所見では中膜間に存在する血栓が enhancement studyで半月状の low density の陰影欠損として描出 され，他の一方に片寄った high density の部が真血管腔で あり，周辺の high density の部は血管外膜とり膜であるら と思われる。この断面図は Friedman ら5の示した血管断 面图のBに類似している.

予後については，血管閉塞の程度や cross circulationの 有無などに上る個体の差で脳虚血症状の違いが大さいが， 内膜自体に注病変がないため，動脈硬化性疾患上り予後良 好であると舟言われる2,9,12．狭窄性变化を呈した症例の 90\%に自然寛解がみられたとの報告もある6!。かし，血 管写で内腔の狭窄が改善したとしても，その血管壁が他の 正常部位と同様の強固さを有するか否かは不明であり，将 来亳血牛，動脈硬化など，加粭に上る变化が加わった場 合，新たに動脈瘤が発生する恐れがある，一力，異常血管 陰影を呈する血管壁は脆弱であり，破裂の危険性が高い。 大きい子のは特に破裂しやすく，早期に外科的な処置を要 すると言われる

治療は，抗凝固療法で良好な結果が得られたといら報告 が多いが5,10)，異常陰影を有する例では破裂の仰険や血栓 の遊離も考えると慎重である心゙をと考光る。しかし，兴虚 血症状を呈している状態で性使用すべきであるう，外科治 療については，㹨害性所見を呈するものては自然宽解皮多 いため，不必要であるとの意見も多い19,121．しかし，こ 
れまで多くの症例で STA MCA anastomosis が行われ，結 果も良好である、本症例でも STA-MCA anastomosis施行 後に急速にしびれ感の消失と頭痛の改善があり，治療効果 があったものと判定された。 3 週後の脳血管撮影では，狭 窄部の一部を除いて改善傾问を示し，完全閉塞を伴わな い，解離性動脈瘤の治療法と乙て沬疑問視する意見も㐫る が，臨床的には十分評伵できるるのと考えられた。また， 狭窄部が完全閉塞に至当場合を了測し，安全な方法と思わ れる、さらに、本例では頸部に動脈瘤様の異常陰影安有 し，内頸動脈の一時的な血行動態の改善にも意義があった むのと考えたが，脳循環測定を欠したため，正確な効果の 注どは不明である。直達手術としては, 解離性動脈溜の切 除上 graft による内頸動脈の再建, explorationを行い, 直 接に，またはFogartyのカテーテルを伐用して stripping をする方法，解離部の血栓遊離に上る脳梗塞を予防寸る几 的での内頸動脈結禁などが行れれている101. 疾患の部位や 大ささ, 症例以上り処置は異なるが, 異常陰影の増大傾问 を呈する例，大きい例では早期の直達手術方必要之考之ら れる。本症例では小動脈瘤と長い狭窄部の両者を有してお り，毛管再建や動脈瘤切除は困難であった。 STA-MCA anastomosis を行ったのち，万一動脈瘤の拡大などがみら れた場合峙結禁する方針であったが，順調な経過を巡っ 心，異常陰影飞小さく，神経症状がごく軽微な症例ては手 術療法は必ずしも必要ではなく，保存的化経過を子ても良 いのではないだろらか。䫓部の過伸展や外傷に注意し，血 王の厳重な管理，食事などによる動脈硬化の予防など，生 活管理も必要である5。

\section{$N$ ま とめ}

頸部内頸動脈汇発生したまれな特発性解離性動脈瘤の症 例を報告した，その発生病理に対する文献的考察を行い， 診断仁打计るCT scan 所見の意義について子，他の血管 のそれと対比して述べた，己らに，予後，治療については 狭窄性変化を呈する例，異常血管陰影を有する例の 2 型に 分计て考察を加えた。

本論文の要旨は，第20回日本脳神経外科学会九州地方会i1985 年6月，神縄)飞招してて発表した。

\section{文献}

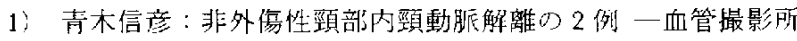
見を中心として一。兴と神 35: 361-366, 1983

2) Cusick JF, Danicls D: Spontaneous reversal of internal artery occlusion. J Neurosurg 54: 811 813, 1984

3) DeBakey ME, Henly WS, Goolcy DA, Morris GC, Crawford ES, Beall AC: Surgical management of dissecting aneurysms of the aorta. J Thorac Cardiovase Surg 49: 130-149, 1965

4) Egan TJ, Neiman HL, Herman RJ, Malave SR, Sanders JH: Computed tomography in the diagnosis of aortic aneurysm dissection or traumatic injury. Radiology 136: 141-146, 1980

5) Friedman WA, Day AL, Quisling RG, Sypert GW, Rhoton AL: Cervical carotid dissecting aneurysms. Neurosurgery 7: 207214,1980

6) Gee W, Kaupp HA, McDonald KM, Lin FZ, Curry JL: Spontaneous dissection of internal carotid arteries. Arch Surg 115: 944949,1980

7)稻垣義明，渡辺滋，諸岡信裕，古田秀夫，山四善重，增 田善炤：解離性大動脈溜画像䧐断. 内科 49:295 303, 1982

8）伊藤義廣，児卡万典，含津純 , 烃角康彦，早川宏：Cystic medial necrosisに上る頭蓋外内项動脈瘤. Neurol Med Chir (Tokyo) 24: 891-896, 1984

9) Kapp JP, Smith RR: Spontaneous resolutions of occlusive lesion of the carotid artery. I Newrosurg 56: 73-79, 1982

10）川口哲郎，朝田雅博，辰尾朋典，玉王紀彦，松本 悟：赛 部队頸動脈の特発性解離性動脈瘤 -2 症例報告上文献的考 察一, 脳神外科 12: 1395-1400, 1984

11) Larde D, Belloir C, Vasile N, Frija J, Fcranc J: Computed tomography of aortic disscction. Radiology 136: 147-151, 1980

12) Mokri B, Sundt TM, Houser OW: Spontancous internal carotid dissection, hemicrania, and Horner's syndrome. Arch Neural 36: 677 680, 1979

13）佐野直樹，西米弘二，吉谷秀一：解離件大動眽溜に於汁万 非観血的検査法一特にRI angiography と CT scan Kつい て一。道南医会誌 $17: 144-147,1982$

14) Thapedi IM, Ashenhurst EM, Rozdilsky B: Spontancous dissecting aneurysms of the internal carotid artery in the neck. Arch Neurol (Chicago) 23: 549-554, 1970

15）上出潤，小林保雄，尾计秀章，大上它一，大死 元，打 田日出夫：現代の CT 診断一腹部血管病変一。現代医療 17 285-292, 1985

〔別刷請求先：干750 山口県下関市上新地町3-3-8, 社会保俟下 関厚生病院脳神経外科，伊藤義廣］ 